\title{
Seasonal patterns of fine root dynamics and their contribution to net primary production in hinoki cypress (Chamaecyparis obtusa) and konara oak (Quercus serrata) forests
}

\author{
Ji Young An $\mathrm{n}^{1,2,3}$. Akira Osawa ${ }^{1,4}$
}

Received: 23 September 2019 / Accepted: 2 September 2020 / Published online: 22 September 2020

(c) The Author(s) 2020

\begin{abstract}
Key message Fine root and litterfall are major contributor of NPP and fine root production may reflect forest productivity in a warm-temperate forest in Japan.

Abstract Forest ecosystems play an important role as the major carbon sink on land, with fine root dynamics and litterfall representing major carbon fluxes. The objectives of this research were to estimate NPP including annual fine root production values, to investigate fine root dynamics and the relationships between above- and belowground organs in konara oak (Quercus serrata) and hinoki cypress (Chamaecyparis obtusa) forests. Litterfall was collected seasonally for 1 year from June 2013. The ingrowth core method and the sequential soil core method were applied with a root litterbag experiment to estimate fine root ( $<2 \mathrm{~mm}$ ) production (FRP), mortality (FRM), and decomposition (FRD) for 1 year (from 2013 to 2014), using the continuous inflow estimate method and the simplified decision matrix. The total NPP ranged from 8.2 to $13.9\left(\mathrm{t} \mathrm{ha}^{-1} \mathrm{yr}^{-1}\right)$, and the sum of aboveground litterfall and FRP accounted for $60 \%$ of the total NPP on average, confirming the significance of above- and belowground litter for the forest NPP as a source of detritus for the decomposer system. In hinoki cypress stand, fine root biomass peaked in the end of winter while fine root necromass showed the highest peak in late summer. In konara oak stand, only very fine root $(<0.05 \mathrm{~mm})$ biomass and necromass demonstrated significant seasonal patterns. The seasonal patterns of fine root production did not differ between forest types and root diameter classes. We found a possible relationship between above- and belowground production and fine root production tended to be high in productive forests. This study improves our understanding of different patterns of carbon dynamics between temperate broadleaved and coniferous forest ecosystems.
\end{abstract}

Keywords Fine root biomass · Fine root necromass · Fine root production · Ingrowth core method · Sequential soil core method $\cdot$ Continuous inflow estimate method

Communicated by A. DesRochers.

Electronic supplementary material The online version of this article (https://doi.org/10.1007/s00468-020-02030-6) contains supplementary material, which is available to authorized users.

Ji Young An

ajy2656@cnu.ac.kr

1 Division of Forest and Biomaterials Science, Graduate School of Agriculture, Kyoto University, Kyoto 606-8502, Japan

2 Institute of Agricultural Science, Chungnam National University, 99 Daehak-ro, Yuseong-gu, Daejeon 34134, Republic of Korea

3 Department of Environment and Forest Resources, College of Agriculture and Life Sciences, Chungnam National University, Daejeon 34134, Republic of Korea

4 Department of Natural Resources, Graduate School of Global Environmental Studies, Kyoto University, Kyoto 606-8502, Japan

\section{Introduction}

Understanding patterns of carbon dynamics in terrestrial forest ecosystems is important in the matter of climate change, because carbon fluxes between forest ecosystems and the atmosphere are closely related to changing concentration of carbon dioxide in the atmosphere (Dixon et al. 1994; Fang et al. 2014; Xu et al. 2014). The amount of carbon fixed by forests is indicated by an important index describing carbon budget of ecosystems, which is called net primary production (NPP). NPP can be used to evaluate the processes of carbon cycling in forest ecosystems (Luo et al. 2002). In most studies on forest productivity such as estimating NPP, belowground fine root (traditionally defined for roots with diameter of less than $2 \mathrm{~mm}$ ) production has been ignored because of difficulty in its estimation; however, it 
may account for up to 70\% of total NPP (Keyes and Grier 1981; Santantonio 1989; Jackson et al. 1997; Gill and Jackson 2000; Janssens et al. 2002; McCormack et al. 2015). Moreover, variations in belowground fine root productivity have not been fully quantified across forest types while aboveground productivity has been widely compared along with an understanding of responses to changing environmental conditions (Gower et al. 2001; Xiao et al. 2003; Girardin and Malhi 2010; Yuan and Chen 2010a, b).

Fine roots primarily have an important role of resource acquisition such as soil nutrient and water (Bardgett et al. 2014). Moreover, fine roots provide organic matter into a soil as a plant litter with rapid turnover rate (Ruess et al. 2003; Yuan and Chen 2010a, b; McCormack et al. 2013; Leppälammi-Kujansuu et al. 2014), and thus influence soil biogeochemical cycles (Sun et al. 2013; Vesterdal et al. 2013). Fine roots show seasonal patterns of production similar to aboveground leaf phenology, seasonal patterns of growth and senescence. It is critical to identify temporal and spatial dynamics of fine roots for understanding how plants respond to changing environment and evaluating productivity of ecosystems. Despite the recognized important role of fine roots and increasing researches on root dynamics, patterns and amount of fine root production have not been fully identified yet, resulting in highly simplified descriptions of belowground processes in models (Ostle et al. 2009; Iversen 2010). McCormack et al. (2014) reported that there was wide variation in the timing of root production among 12 temperate tree species, with some species showing a single root flush in early summer and other species presenting either a uniform pattern or multiple peaks of root production. Also, large inter-annual differences of root production were found even within species. Similarly, we can assume that seasonal patterns of fine root production vary between forest types because of internal (e.g., genotype of plant species and species composition of forests) and external (e.g., climatic conditions, soil properties, and nutrient availability) factors (Steele et al. 1997; Pregitzer et al. 2000; Tierney et al. 2003; Majdi et al. 2005; Brassard et al. 2009).

While fine root production constitutes a large proportion of annual NPP, only a few studies reported on both belowand aboveground production simultaneously or the relationship between compartments of NPP (Helmisaari et al. 2002). Understanding the relationships between above- and belowground production patterns is also important for improving our knowledge about forest production processes (Zak and Pregitzer 1998; Trumbore and Gaudinski 2003; Litton et al. 2007), because belowground fine root dynamics are closely related with aboveground physiological processes and production (Satomura et al. 2006). Although several studies reported the positive relationship between fine root production and aboveground production/or NPP (Nadelhoffer et al. 1985; O'Grady et al. 2006; Van Do et al. 2015a; Do et al. 2015b), there is still no general consensus about this relationship in forests.

Fine root production and turnover rates vary considerably depending on many endogenous and exogenous factors such as forest type, soil properties, and climatic conditions (Nadelhoffer and Raich 1992; Eissenstat and Yanai 1997). The estimates of fine root production and turnover also depend on measurement and calculation methods, even though several methods have been developed and used to estimate fine root production, such as the sequential soil core (Persson 1980; Ostonen et al. 2005), ingrowth core (Finér et al. 1997; Ostonen et al. 2005) minirhizotron (Hendrick and Pregitzer 1996; Majdi 1996), nitrogen budget (Nadelhoffer et al. 1985), and carbon balance (Ågren et al. 1980) methods. Several calculation methods for fine root dynamics are also available, such as decision matrix (Fairley and Alexander 1985; Hertel et al. 2009), maximum-minimum (Keyes and Grier 1981; Hertel and Leuschner 2002) the compartment flow model (Santantonio and Grace 1987), and others. The decision matrix has been widely used for sequential soil coring and ingrowth coring. However, the decision matrix is limited, as this method provides underestimates of the variable of interest, because some terms of production, mortality, and decomposition must be neglected in specific calculations. Recently, the continuous inflow estimate method was suggested by Osawa and Aizawa (2012), with the addition of a simple root litter bag experiment. This approach provided more reliable estimates of fine root production, mortality, and decomposition.

The objectives of this study were to investigate fine root dynamics with seasonal patterns of fine root mass, production, mortality, and to relate belowground growth parameters to aboveground organs in hinoki cypress and konara oak forest of Japan. We used both the sequential soil core and ingrowth core methods to estimate fine root dynamics and to allow a comparison between the two methods. We hypothesized that aboveground and belowground production are positively related and that seasonal patterns of fine root production vary between different forest types.

\section{Materials and methods}

\section{Study site and stand descriptions}

This study was conducted in hinoki cypress (C. obtusa) and konara oak $(Q$. serrata) stands in the Ryukoku Forest in Shiga, Japan ( $34^{\circ} 58^{\prime} \mathrm{N}, 135^{\circ} 56^{\prime} \mathrm{E}, 130 \mathrm{~m}$ a.s.l.). The Ryukoku Forest is a secondary forest composed primarily of $Q$. serrata Thunb. and Pinus densiflora Sieb. et Zucc. The soil of the study area is characterized by sand and small round gravels and is classified as yellowish brown forest soil of the Kobiwako group derived from lacustrine sediments of 
Cenozoic origin (Osawa and Aizawa 2012; Ministry of Land Infrastructure Transportation and Tourism 1982). Soil bulk density is $1.23 \mathrm{~g} \mathrm{~cm}^{-3}$ in cypress stand and $1.26 \mathrm{~g} \mathrm{~cm}^{-3}$ in oak stand with a texture of sandy clay loam (Nakahata and Osawa 2017). To estimate NPP and investigate fine root dynamics, we established four study plots (Table 1) in ca. 80-year-old hinoki cypress plantations (CO1 and CO2) and broadleaved secondary forests composed primarily of konara oak as canopy trees (QS2 and QS3). The plots also contain some canopy and subcanopy trees of Clethra barbinervis, Ilex pendunculosa, Juniperus rigida, Eurya japonica, and Cleyera japonica. In QS2 plot, the relative basal area was $12 \%$ for C. barbinervis, $5 \%$ for I. pendunculosa, and $5 \%$ for C. obtusa. In QS3 plot, I. pendunculosa, J. rigida, E. japonica, and $C$. japonica accounted for $24,7,6$, and $6 \%$ of total basal area, respectively.

The mean annual precipitation from 1981 to 2010 was $1530 \mathrm{~mm}$, and the temperature was $14.9^{\circ} \mathrm{C}$. The annual mean temperatures were 15.6 in 2013 and $15.1{ }^{\circ} \mathrm{C}$ in 2014 . The annual precipitation was $1589 \mathrm{~mm}$ in 2013 and $1465 \mathrm{~mm}$ in 2014. The mean monthly temperatures in 2013 were higher than the long-term averages for April to October (Fig. 1). The precipitation in September 2013 was approximately 2.4 times greater than expected based on the long-term average, while the lowest precipitation was observed in July 2013, which was $47 \%$ of the usual level (Fig. 1). The total amounts of precipitation for April to June 2014 were less than the long-term values

Table 1 Stand descriptions of the hinoki cypress (CO1 and CO2) and konara oak (QS2 and QS3) stands in the Ryukoku Forest of Japan

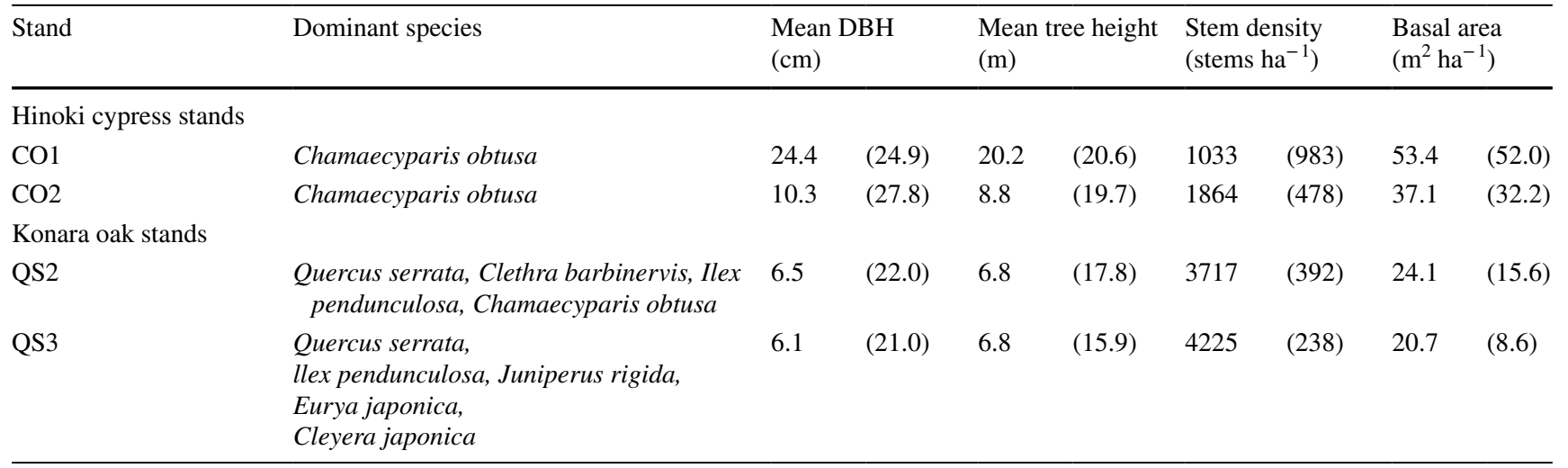

Values presented in parentheses indicate those obtained for canopy tree species (Chamaecyparis obtusa in hinoki cypress stands of CO1 and $\mathrm{CO} 2$; Quercus serrata in konara oak stands of QS2 and QS3). Understory vegetation with a diameter at breast height of less than $2 \mathrm{~cm}$ was ignored. Dead trees were excluded

Fig. 1 Mean monthly temperatures and monthly precipitation sums (data from the Japan Meteorological Agency)

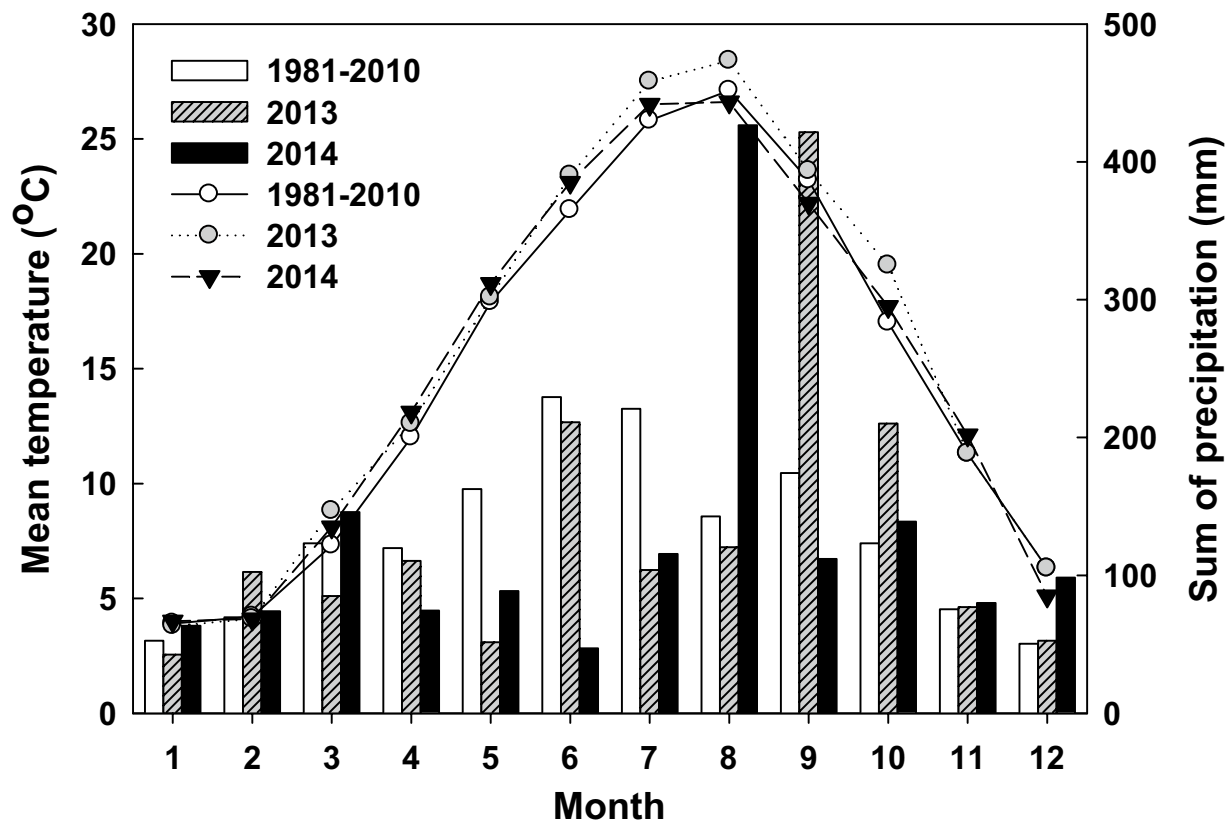


for those months; in addition, the precipitation in June 2014 was remarkably low, at $21 \%$ of the normal amount.

\section{Vegetation censuses and biomass estimation}

At the beginning and end of the 2013 and 2014 growing seasons, the tree diameter at breast height (DBH, in $\mathrm{cm}$ ) was measured for all trees larger than $2 \mathrm{~cm}$ in DBH. Because measuring tree height in fully closed forest stands is not always easy and accurate, the tree height $(\mathrm{H}$, in $\mathrm{m})$ was estimated using the following hyperbolic equation (Ogawa and Kira 1977):

$\frac{1}{H}=\frac{1}{\left(a \times D B H^{b}\right)}+\frac{1}{H_{\max }}$

where $a$ and $b$ are plot-specific constants and $H_{\max }$ is another constant representing the asymptotic tree height. The parameters of the equation were determined by nonlinear regression analysis, based on subsamples of trees for which both tree height and DBH were measured in each plot $\left(r^{2}=0.96-0.99\right.$ for each parameter, $\left.p<0.0001\right)$.

The biomass of stems, branches and coarse roots of all trees in each plot were estimated from DBH $(\mathrm{cm})$ and tree height (m) using the allometric equations presented below. The following allometric equations were used for hinoki cypress trees (Hagihara et al. 1993):

$$
\begin{aligned}
& W_{s}(k g)=0.01652\left(D_{0.1}^{2} H\right)^{0.9983} \\
& W_{b}(k g)=0.001669\left(D_{0.1}^{2} H\right)^{1.0145} \\
& W_{r}(k g)=0.006001\left(D_{0.1}^{2} H\right)^{0.9843}
\end{aligned}
$$

where $D_{0.1}$ is stem diameter at a height of $H / 10$ and $W_{s}$, $W_{b}$ and $W_{r}$ are the biomass (based on dry weight) of stems, branches and coarse roots of hinoki cypress trees, respectively. We did not measure $D_{0.1}$ in 2013 and 2014 so $D_{0.1}$ was estimated using the equation $D_{0.1}=0.9322 D+0.9222$ developed from hinoki cypress trees for which both $D$ and $D_{0.1}$ were measured in November 2012 .

We used the following allometric equations developed in the Ryukoku Forest (Miyaura et al., personal communication) to estimate aboveground biomass of deciduous and evergreen broadleaved trees and conifers other than hinoki cypress.

For deciduous broadleaved trees:

$W_{s}(k g)=0.122 D^{2.14}$

$$
W_{b}(k g)=0.0298 D^{2.26}
$$

where $W_{s}$ and $W_{b}$ are the biomass (based on dry weight) of stems and branches of deciduous broadleaved trees, respectively.

For evergreen broadleaved trees:

$W_{s}(k g)=0.177 D^{1.96}$

$W_{b}(k g)=0.0862 D^{1.88}$

where $W_{s}$ and $W_{b}$ are the biomass (based on dry weight) of stems and branches of evergreen broadleaved trees, respectively.

For conifers other than hinoki cypress:

$W_{s}(k g)=0.157 D^{2.02}$

$W_{b}(k g)=0.00210 D^{3.05}$

where $W_{s}$ and $W_{b}$ are the biomass (based on dry weight) of stems and branches of conifers, respectively.

Because the allometric equation for coarse roots was not developed in the Ryukoku Forest, we used the equation, $W_{r}(k g)=0.0093 D_{0}^{2.5015}$ (Cheng 2017) developed using the data from the Yamashiro Experimental Forest (Dannoura et al. 2006), where $W r$ is the biomass of coarse roots of broadleaved and coniferous trees, and $D_{0}(\mathrm{~cm})$ is the diameter at basal portion of stem. We did not measure $D_{0}$ in 2013 and 2014 so $D_{0}$ was estimated using the equation $D_{0}=1.527 D^{0.962}$ developed from trees for which both $D$ and $D_{0}$ were measured in 2007 in the Ryukoku Forest (Naruse 2008).

\section{Litterfall collection and sample processing}

Seven square-shaped litter traps with a collection area of $1 \mathrm{~m}^{2}$ at a height of $1 \mathrm{~m}$ above the forest floor were randomly deployed in CO1 in March 2010. The traps were emptied monthly starting in April 2010 (Ishii 2014). In CO1, litterfall samples collected from June 2013 to June 2014 were used for the present study and they were processed in the same manner as the others. We established twelve litter traps with a circular opening and a collection area of $0.283 \mathrm{~m}^{2}$ at a height of $1 \mathrm{~m}$ above the forest floor, with three traps on each of four transects, in each of the remaining plots (CO2, QS2, and QS3) to estimate annual litterfall production. The litter traps were set out in March 2013 and emptied in June and August 2013 and in January, March and June 2014. The collected litterfall was stored under shade and cool condition in the laboratory before processing. Six litter traps were randomly selected from each plot and processed for this study. The samples were sorted into leaves, twigs (diameter $<1 \mathrm{~cm}$ ), and others which is the remaining fraction including bark, seeds, and miscellaneous items. Leaf 
litterfall was further divided into leaves of canopy tree species (hinoki cypress trees in $\mathrm{CO} 1$ and $\mathrm{CO} 2$, konara oak trees in QS2 and QS3) and other leaves of from other tree species. The sorted litterfall was oven-dried at $65{ }^{\circ} \mathrm{C}$ for $72 \mathrm{~h}$ and weighed.

\section{Fine roots $(<2 \mathrm{~mm})$ measurement}

We used the ingrowth core method ('ic' denotes the ingrowth core method) to estimate fine root production (FRPic), mortality (FRMic) and decomposition (FRDic) in all study plots (CO1, CO2, QS2, and QS3). The ingrowth core method uses measurements of fine root growth into a root-free medium placed in the soil profile to estimate production (Vogt and Persson 1991; Nadelhoffer and Raich 1992). Three parallel sampling lines, which were separated from each other by at least 10 meters, were established in all plots except CO1. Each sampling line had four points placed at five-meter intervals for the ingrowth core. In the case of $\mathrm{CO} 1$, six subplots with a size of $5 \mathrm{~m} \times 5 \mathrm{~m}$ were randomly selected for ingrowth core installation, and two points from each subplot were randomly selected for ingrowth cores. In total, 48 ingrowth cores (12 ingrowth cores in each plot) were installed in early June 2013 in all plots. At the beginning of ingrowth core installation, the hole that was needed to place a cylindrical tube $32 \mathrm{~mm}$ in diameter and $21 \mathrm{~cm}$ in length was excavated by pounding a stainless steel tube (38 $\mathrm{mm}$ in diameter and $45 \mathrm{~cm}$ in length) into the ground. The cylindrical tube, which is used for the ingrowth core frame, is made of plastic mesh, with approximately $3 \mathrm{~mm}$ mesh openings and a mesh bottom made of the same material as the cylinder wall (Osawa and Aizawa 2012). The cylinder was placed in the hole and filled separately with a root-free soil to a soil depth between the upper $(0-5 \mathrm{~cm}$ in depth) and lower layer (5-21 cm in depth). To make a rootfree soil, soil divided into the upper and lower layers was collected from the study site; the soil profile of the Ryukoku Forest was distinguished by its color between the upper and lower layer at a depth of approximately $5 \mathrm{~cm}$, although the properties of the soil were not analyzed. The soil was sieved through a sieve with a mesh size in $5 \mathrm{~mm}$ and then remaining root particles were visually handpicked from the sieved soil to remove all living and dead roots. The gap between the cylinder and the inner wall of the cored hole was also filled with the same soil that was used to fill the ingrowth cores. In December 2013, six ingrowth cores were chosen randomly, removed from the ground by cutting around the periphery of the ingrowth cores approximately $2 \mathrm{~cm}$ away from the ingrowth core wall with a knife, and pulling the cores out by hand. In June 2014, the remaining six ingrowth cores were collected using the same method in each plot. The collected ingrowth cores were placed in plastic bags and stored in a freezer until the time of processing. The cylinders were divided into the upper $(0-5 \mathrm{~cm})$ and lower $(5-21 \mathrm{~cm})$ soil layers, woody fine roots were extracted from the upper and lower layers of the soil samples, and the sorted roots were washed carefully with tap water. Living and dead roots were separated and further sorted into two diameter classes (very fine root, $0-0.5 \mathrm{~mm}$; fine root $0.5-2 \mathrm{~mm}$ ). Dead fine roots are distinguished by their dark color, low strength, and low resilience (Vogt and Persson 1991; Hishi and Takeda 2005a, b). The microscope was used when it was difficult to distinguish dead roots. The washed roots were oven-dried at $65^{\circ} \mathrm{C}$ for $72 \mathrm{~h}$ and weighed.

To investigate fine root dynamics, a total 140 soil cores were collected sequentially ('sc' denotes the sequential core method) at 2-month intervals in $\mathrm{CO} 2$ and QS3 using the same stainless steel tube that was used for the ingrowth core study from June 2013 to June 2014. Twelve parallel sampling lines, which were separated from each other by at least $1 \mathrm{~m}$, were established in each plot. Each sampling line included ten points placed at two-meter intervals for sequential soil cores. Every 2 months (totally for a total of seven times for over a year), ten soil cores, which were placed to a depth of $21 \mathrm{~cm}$, were collected from randomly selected points in each plot. Collected soil cores were processed in the same way described for the ingrowth cores; however, the soil cores were not divided by soil depth.

In this study, we collected soil cores in upper soil layer $(0-21 \mathrm{~cm})$ because of practical difficulties in collecting soil core samples below $20 \mathrm{~cm}$ due to the presence of gravel. According to previous studies conducted in the same research site, fine roots in the upper soil layer accounted for approximately $70 \%$ of those in $0-50 \mathrm{~cm}$ soil depth (Hattori 2011). Thus, we assumed that belowground fine roots in $0-21 \mathrm{~cm}$ soil depth covered a high proportion of total belowground productivity in this research site.

\section{Root litterbag experiment}

To estimate the decomposition ratio of dead fine roots, we conducted root litter bag experiments in all plots for 1 year from June 2013. Regardless of species, living fine roots were collected from each plot at the study site, washed, dried at room temperature, divided into three diameter classes, and used as dead fine roots in the litter bags in this experiment. We used flat, square litter bags made of a 'root-impermeable water-permeable (RIWP) sheet®' (Toyobo Co., Osaka, Japan). The bags had a pore size of approximately $6 \mu \mathrm{m}$ to prevent fine roots from growing into the bag; however, fine particles of soil, rain water, and other microorganisms could penetrate through the sheet (Osawa and Aizawa 2012). A known amount of dead fine roots of three diameter classes was added to each of the root litter bags separately, and a root-free soil divided by soil depth was also included in the litter bags to improve the physical contact of the soil 
particles with the dead roots in the bag. In June 2013, 36 root litter bags $(3$ diameter classes $\times 2$ soil depths $\times 6$ replicates $=36$ bags) were buried separately at different soil depths at randomly selected points in each plot. In December 2013, litter bags that were buried for 6 months were collected, moved to the laboratory and processed. Decomposing dead fine roots were removed from the litter bag, carefully washed with tap water, oven-dried at $65^{\circ} \mathrm{C}$ for $72 \mathrm{~h}$ and weighed. In January 2014, the same procedure that was used for the root litter bag experiment was repeated to estimate the decomposition ratio of dead fine roots from January to June 2014.

\section{Calculation of root production, mortality, decomposition}

For ingrowth cores, fine root production $\left(g_{i j}\right)$, mortality $\left(m_{i j}\right)$ and decomposition $\left(d_{i j}\right)$ were calculated using the continuous inflow estimate method (Osawa and Aizawa 2012), as follows:

Fine root production : $g_{i j}=\Delta B+\Delta N+d_{i j}$

Fine root mortality : $m_{i j}=\Delta N+d_{i j}$

Fine root decomposition : $d_{i j}=-\Delta N-\left(\Delta N / \gamma_{i j}+N_{i}\right) \cdot \ln \left(1-\gamma_{i j}\right)$

where $\Delta \mathrm{B}$ and $\Delta \mathrm{N}$ are the change in fine root biomass and necromass between times $\mathrm{i}$ and $\mathrm{j}(\mathrm{i}<\mathrm{j})$, respectively; $N_{i}$ is the amount of fine root necromass in the core at time $i$; and $\gamma_{i j}$ is the decomposition ratio of fine root necromass estimated from the root litterbag experiment, as follows:

Decomposition ratio of fineroot necromass : $\gamma_{i j}=1-N_{j}^{C} / N_{i}^{C}$ where $N_{i}^{C}$ and $N_{j}^{C}$ are the mass of dead fine roots in the litter bag at times i and $j$, respectively. Details of the calculation are described in a previous study (Osawa and Aizawa 2012). The $68 \%$ confidence limits of the estimated means were calculated using the bootstrap method with the bias-corrected percentile approach by randomly sampling a set of mass data $\mathrm{n}$ times with replacement (when the sample size is $\mathrm{n}$ ) to obtain the means. The process was then repeated 1000 times to generate the $68 \%$ confidence interval (CI) (Efron 1979; Efron and Gong 1983; Osawa and Aizawa 2012).

For sequential soil cores in $\mathrm{CO}_{2}$ and QS3, fine root production (FRPsc), mortality (FRMsc), and decomposition (FRDsc) were calculated using the simplified decision matrix (Table 2) of Yuan and Chen (2013), because many negative values occurred when we applied the continuous inflow estimate method and the bootstrap method. The simplified decision matrix proposed by Yuan and Chen (2013) is modified version from Fairley and Alexander (1985). The decision matrix is a widely used method to estimate fine root
Table 2 Simplified decision matrix (Yuan and Chen 2013) for calculating production, mortality and decomposition of fine roots in $\mathrm{CO} 2$ and QS3 in the Ryukoku Forest

\begin{tabular}{llll}
\hline If & Production & Mortality & Decomposition \\
\hline$\Delta \mathrm{B}+\Delta \mathrm{N} \geq 0$ & & & \\
$\Delta \mathrm{N} \geq 0$ & $\Delta \mathrm{B}+\Delta \mathrm{N}$ & $\Delta \mathrm{N}$ & 0 \\
$\Delta \mathrm{N}<0$ & $\Delta \mathrm{B}$ & 0 & $|\Delta \mathrm{N}|$ \\
$\Delta \mathrm{B}+\Delta \mathrm{N}<0$ & & & \\
$\Delta \mathrm{N} \geq 0$ & $\Delta \mathrm{B}$ & 0 & $|\Delta \mathrm{N}|$ \\
$\Delta \mathrm{N}<0$ & 0 & $|\Delta \mathrm{B}|$ & $|\Delta \mathrm{B}+\Delta \mathrm{N}|$ \\
\hline
\end{tabular}

$\Delta=$ changes in root biomass or necromass, $B=$ living root biomass, $N=$ dead root necromass

If $\Delta \mathrm{B}+\Delta \mathrm{N} \geq 00$ and $\Delta \mathrm{N} \geq 00$, the fine root production is calculated as $\Delta \mathrm{B}+\Delta \mathrm{N}$

production, mortality, and decomposition during a certain period, based on the changes of living and dead fine root mass.

\section{NPP estimation}

The total NPP was calculated based on the sum of changes in the biomass of aboveground organs (stems and branches) and coarse roots, as well as amounts of annual litterfall mass and annual fine root production. We defined aboveground net primary production (ANPP) as the sum of aboveground (stems and branches) biomass increment and litterfall mass for 1 year. Litterfall mass was combined into leaf (sum of dominant species and other species leaf) and other litterfall (sum of twigs and others). Belowground production was calculated as the sum of coarse root biomass increment, and fine root production estimated by the ingrowth core method.

\section{Statistical analyses}

We tested the significance of differences in each litterfall fraction across the stands using one-way analysis of variance (ANOVA). Three-way ANOVA was conducted to examine the effects of stand, sampling time (month), and root diameter on fine root biomass, necromass, production, mortality, and decomposition. Tukey's HSD (honestly significant difference) test was applied to determine significant differences between means $(p<0.05)$. We used a linear regression model analysis to test the relationships between above- and belowground mass or production, such as the relationship between basal area and fine root biomass and the relationship between leaf litterfall mass and fine root production. When necessary, data was transformed properly before the statistical analyses. All statistical analyses were performed using the SAS 9.2 software (SAS Institute, Inc., USA). 


\section{Results}

\section{Above- and belowground production in hinoki cypress and konara oak forests}

The total NPP ranged from 8.2 to $13.9 \mathrm{t} \mathrm{ha}^{-1} \mathrm{yr}^{-1}$, with means of 11.8 and $8.4 \mathrm{tha}^{-1} \mathrm{yr}^{-1}$ in hinoki cypress forest and konara oak forest, respectively (Fig. 2a). The aboveground NPP (ANPP) ranged from 6.7 to $11.0 \mathrm{t} \mathrm{ha}^{-1} \mathrm{yr}^{-1}$, which accounted for an average of $81 \%$ of the total NPP. Belowground production ranged from 1.6 (in QS3) to 2.8 (in CO1) $\mathrm{t} \mathrm{ha}^{-1} \mathrm{yr}^{-1}$, which represented an average of $19 \%$ of the total NPP. The proportion of FRPic to belowground production in all stands was higher than that of coarse

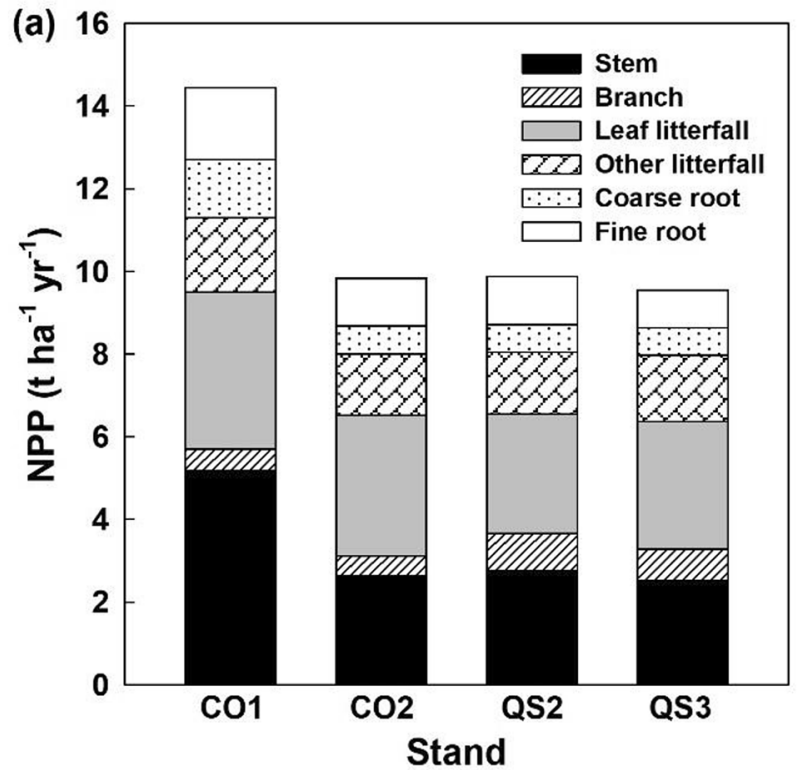

Fig. 2 Above- and belowground net primary production (NPP) in all stands in the Ryukoku Forest. NPP was calculated based on the sum of changes in the biomass of aboveground stem, branches and coarse roots, as well as annual litterfall mass and fine root production. Biomass increment of stem, branches and coarse roots was calculated root production to belowground production, which ranged from 51 to $53 \%$ (Fig. 2b). FRPic accounted for 9 to $11 \%$ of total NPP. Annual FRPsc values were $5.4 \mathrm{ha}^{-1} \mathrm{yr}^{-1}$ in $\mathrm{CO}_{2}$ and $4.0 \mathrm{tha}^{-1} \mathrm{yr}^{-1}$ in QS3 (Table S2). The proportions of fine root production estimated using sequential soil cores were 53 and $36 \%$ of belowground production, resulting in 30 and $22 \%$ of the total NPP, in stands $\mathrm{CO}_{2}$ and QS3, respectively.

\section{Annual litterfall mass}

The annual litterfall mass ranged from 436 to $560 \mathrm{~g} \mathrm{~m}^{-2}$ $\mathrm{yr}^{-1}$ and did not differ significantly among stands $(p=0.42$; Table 3). Leaf litterfall of canopy tree species (hinoki cypress trees in $\mathrm{CO} 1$ and $\mathrm{CO} 2$; konara oak trees in QS2 and

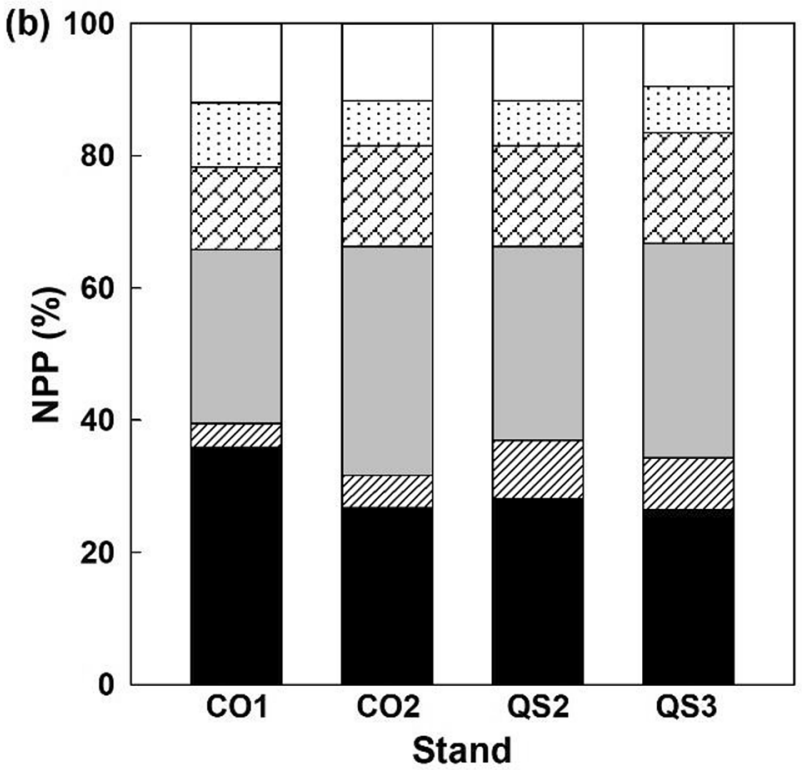

by the allometric equations. Annual litterfall mass was estimated by the litter traps. Annual fine root production was estimated by the ingrowth core method and the continuous inflow estimated method (Osawa and Aizawa 2012). a NPP $\left(\mathrm{t} \mathrm{ha}^{-1} \mathrm{yr}^{-1}\right)$ and b NPP (\%)
Table 3 Annual litterfall mass $\left(\mathrm{g} \mathrm{m}^{-2}\right)$ sorted into four parts (leaves (hinoki cypress in $\mathrm{CO} 1$ and $\mathrm{CO} 2$, konara oak in QS2 and QS3), other leaves, twigs, and the remaining fraction) for all study plots in the Ryukoku Forest

\begin{tabular}{lccccccccccc}
\hline & Leaves & & \multicolumn{2}{l}{ Other leaves } & Twigs & \multicolumn{3}{c}{ Others } & \multicolumn{3}{c}{ Total } \\
\hline $\begin{array}{l}\text { Hinoki cypress } \\
\text { CO1 }\end{array}$ & & & & & & & & & & \\
CO2 & 256.5 & $(36.7) \mathrm{a}$ & 26.6 & $(7.1) \mathrm{b}$ & 67.3 & $(12.3) \mathrm{a}$ & 109.7 & $(19.1) \mathrm{a}$ & 560.1 & $(72.3) \mathrm{a}$ \\
Konara oak & & & & & & & & & & & \\
QS2 & 133.1 & $(17.8) \mathrm{b}$ & 154.8 & $(21.8) \mathrm{a}$ & 85.0 & $(21.9) \mathrm{a}$ & 62.9 & $(14.1) \mathrm{a}$ & 435.8 & $(14.1) \mathrm{a}$ \\
QS3 & 135.5 & $(16.6) \mathrm{b}$ & 179.3 & $(36.5) \mathrm{a}$ & 101.7 & $(21.6) \mathrm{a}$ & 63.1 & $(9.5) \mathrm{a}$ & 479.5 & $(24.2) \mathrm{a}$ \\
\hline
\end{tabular}

Standard errors are shown in parentheses $(n=6)$. Mean values presented with the same letters are not significantly different among stands within each column $(p<0.05$; Tukey's HSD test) 
QS3) and other leaf litterfall differed significantly among stands $(p<0.05)$. Regardless of tree species, the leaf litterfall mass was a major fraction of the total litterfall, with values of 69 and $66 \%$ of total litterfall mass in hinoki cypress stands and konara oak stands, respectively. Other leaf litterfall mass was higher than leaf litterfall mass for konara oak trees in QS2 and QS3, accounting for an average of 55\% of the total leaf litterfall. In contrast, other leaf litterfall mass comprised an average of $14 \%$ of the total leaf litterfall in hinoki cypress stands. The proportion of twigs and other fractions, such as bark and seeds, to total litterfall mass for both types of stand was $16 \%$, on average.

\section{Annual fine root $(<2 \mathrm{~mm})$ production, mortality, and decomposition}

The annual FRPic ranged from 90 to $159 \mathrm{~g} \mathrm{~m}^{-2} \mathrm{yr}^{-1}, 50$ to $88 \mathrm{~g} \mathrm{~m}^{-2} \mathrm{yr}^{-1}$ for FRMic, and 1 to $8 \mathrm{~g} \mathrm{~m}^{-2} \mathrm{yr}^{-1}$ for FRDic, respectively (Table S1). No roots larger than $2 \mathrm{~mm}$ in diameter were found in the 1-year ingrowth cores. The values of FRPic and FRMic were high in hinoki cypress stand, $\mathrm{CO} 1$ which had high density of canopy tree. Annual FRPic, FRMic, and FRDic of less than $2 \mathrm{~mm}$ in diameter accounted for averages of 83,94 , and $89 \%$ of the total FRP, FRM, and FRD for all diameter classes, respectively (Table S1).

The annual FRPsc, FRMsc, and FRDsc values were 540, 585, and $671 \mathrm{~g} \mathrm{~m}^{-2} \mathrm{yr}^{-1}$ in $\mathrm{CO} 2$ and 400, 410, and $499 \mathrm{~g}$ $\mathrm{m}^{-2} \mathrm{yr}^{-1}$ in QS3, respectively. All values were higher in $\mathrm{CO} 2$ than in QS3 ( $p<0.05$; Table S2). Compared with the annual FRPic values, the annual FRPsc values were 5.8 and 4.4 times greater in $\mathrm{CO} 2$ and QS3, respectively.

\section{Seasonal dynamics of fine root bio- and necromass in hinoki cypress and konara oak stands}

Fine root biomass estimated by the sequential soil core method differed significantly between stands $(p=0.008)$, sampling times $(p<0.0001)$ and root diameter $(p<0.0001$; Table 4). In both stands, fine root biomass was about two times higher in February 2014 than in October 2013 (Fig. 3a and $b$ ) and it was attributed to high biomass of larger fine root $(0.5-2 \mathrm{~mm})$ in February 2014 (Fig. 3a). Fine root necromass was also significantly different between stands $(p<0.0001)$, sampling times $(p<0.0001)$ and root diameter $(p=0.002$; Table 4$)$. Also, the three-way interaction between stand and time related to root diameter significantly affected fine root necromass $(p=0.03)$. In this study area, seasonal patterns of fine root necromass between stands were significantly influenced by root diameter. Very fine root $(<0.5 \mathrm{~mm})$ necromass was higher in summer season (June-August in 2013) than other seasons and this tendency was remarkable in hinoki cypress stand $\mathrm{CO} 2$ (Fig. $3 \mathrm{c}$ and d). On the other hand, larger fine root necromass was only significantly different among sampling times in hinoki cypress stand, representing the higher necromass in early winter (November) than summer and spring (August and April) (Fig. 3c).

\section{Seasonal patterns of fine root production, mortality, and decomposition in hinoki cypress and konara oak stands}

Seasonal FRPsc was not significantly different between stands $(p=0.12)$, months $(p=0.18)$, and root diameter $(p=0.09)$ according to the result of a three-way ANOVA (Table 5). However, FRMsc was significantly different between stands $(p=0.008)$ and months $(p=0.006)$ with the interaction effect between month and diameter, and FRDsc differed significantly across months $(p=0.03$; Table 5$)$. In hinoki cypress stand $\mathrm{CO} 2$, the mortality of very fine root $(<0.5 \mathrm{~mm})$ was high in early summer (Fig. $4 \mathrm{c})$ resulted from high necromass of very fine root in August 2013.

\section{Relationships between above- and belowground production}

FRPic showed no significant correlations with the leaf litterfall mass $\left(p=0.18, \mathrm{r}^{2}=0.67\right)$ and the basal area increment ( $\left.p=0.29, \mathrm{r}^{2}=0.50\right)$ (Fig. 5a, b). However, there was a positive tendency for the relationship between above- and belowground production ( $\left.p=0.06, r^{2}=0.87\right)$ (Fig. 5c). Also, the relationship between NPP and FRPic was not statistically significant but approached trend levels of significance $\left(p=0.058, r^{2}=0.89\right)$.

\section{Discussion}

Litterfall and fine roots, which represent major carbon fluxes in forest ecosystems, contributed about $60 \%$ of the total NPP in hinoki cypress and konara oak stands in the Ryukoku Forest, confirming the significance of above- and belowground litter for forest NPP as inputs of detritus to the decomposer system. In addition, belowground production accounted for $19 \%$ on average of NPP in this study area. Tateno et al. (2004) conducted a study of biomass and net primary production in a cool-temperate deciduous forest in Japan in relation to topographical changes. They also estimated fine root production using the ingrowth core method. According to their results, the total NPP ranged from 8.8 to $14.1 \mathrm{t} \mathrm{ha}^{-1} \mathrm{yr}^{-1}$, and the proportion of fine root production to total belowground production was 60 to $90 \%$; those levels are higher than the percentages reported in this study. Moreover, their results showed that the belowground production tended to increase with decreasing soil $\mathrm{N}$ availability and that fine root production was the main contributor to this tendency. The general allocation pattern of NPP indicates 
Hinoki cypress (CO2)

Konara oak (QS3)

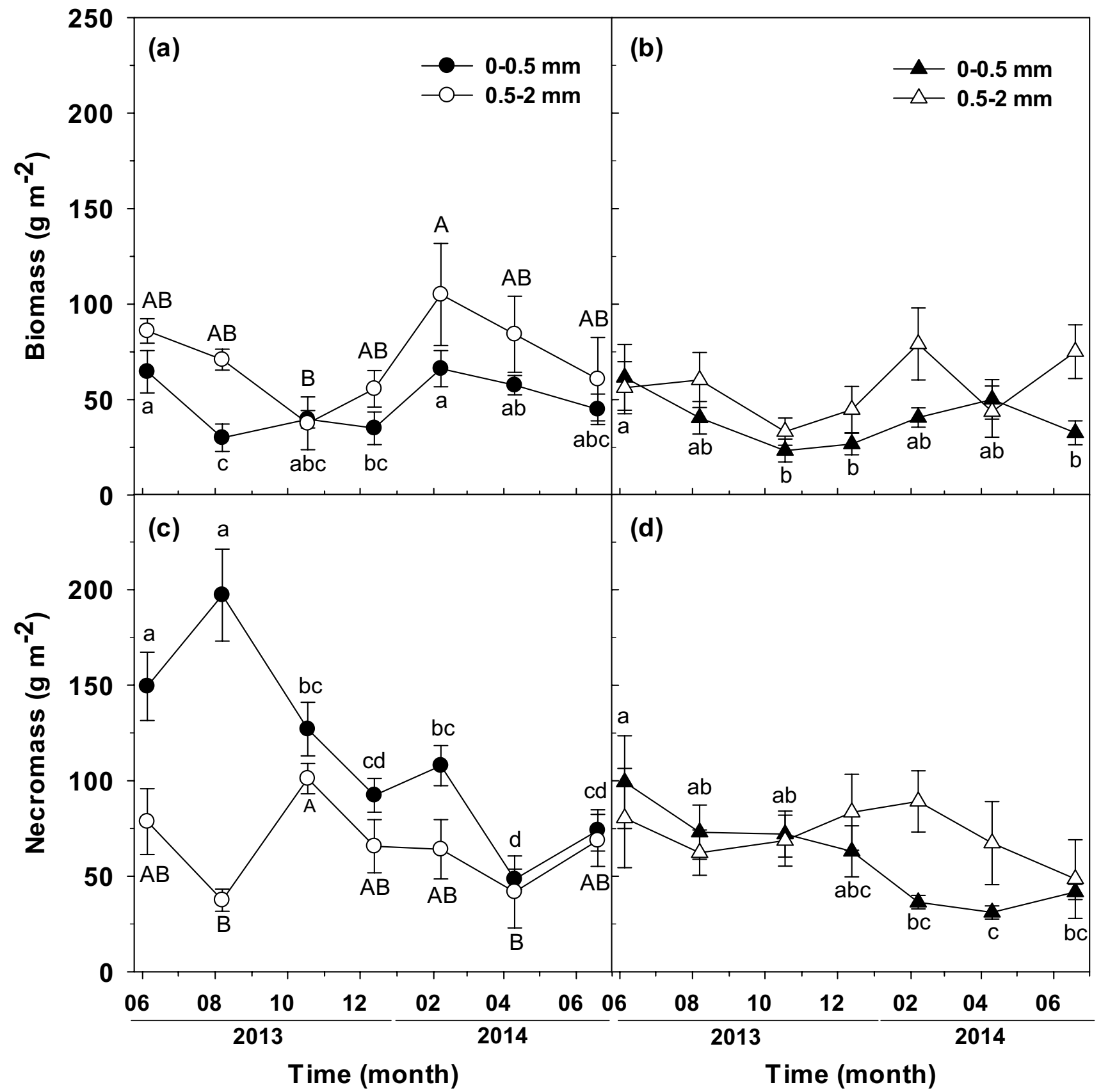

Fig. 3 Seasonal dynamics of fine root biomass (a, b) and necromass (c, d) measured by sequential soil cores from Jun 2013 to June 2014 in the CO2 (a, c) and QS3 (b, d) stands. Vertical bars indicate standard errors $(n=10)$. Mean values with the same letters do not differ

that more NPP is allocated to the roots under unfavorable site conditions (Keyes and Grier 1981; Vogt et al. 1987). In contrast, Yuan and Chen (2012a, b) reported that fine root production increased along natural $\mathrm{N}$ and $\mathrm{P}$ soil gradients in terrestrial ecosystems through a global analysis study. They also implied that the proportion of root production to NPP significantly across months within each stand $(p<0.05$; Tukey's HSD test). No significant differences were detected in fine root $(0.5-2 \mathrm{~mm})$ biomass and necromass in QS3 across sampling times

decreased with soil nutrients, resulting in changes of carbon allocation pattern, although the absolute value of fine root production may increase with increasing soil nutrients. Understanding patterns of belowground carbon allocation can improve our insights into plant nutrient demand in forest ecosystems (Iversen and Norby 2008). Because fine roots 
Table $4 \mathrm{~F}$ and $\mathrm{p}$ values of the effects of stand (S), sampling time (T), and fine root diameter (D) on fine root biomass and necromass measured by the sequential soil core in $\mathrm{CO} 2$ and QS3 using a three-way ANOVA

\begin{tabular}{lccc}
\hline & df & $F$ value & $p$ value \\
\hline Biomass & & & \\
Stand (S) & 1 & 7.17 & 0.0079 \\
Time (T) & 6 & 5.39 & $<0.0001$ \\
Diameter (D) & 1 & 19.33 & $<0.0001$ \\
S*T & 6 & 0.78 & 0.5875 \\
S*D & 1 & 0.51 & 0.4764 \\
T*D & 6 & 1.21 & 0.3026 \\
S*T*D & 6 & 0.82 & 0.5553 \\
Necromass & & & \\
Stand (S) & 1 & 16.88 & $<0.0001$ \\
Time (T) & 6 & 6.51 & $<0.0001$ \\
Diameter (D) & 1 & 9.73 & 0.002 \\
S*T & 6 & 1.51 & 0.175 \\
S*D & 1 & 26.52 & $<0.0001$ \\
T*D & 6 & 5.14 & $<0.0001$ \\
S*T*D & 6 & 2.34 & 0.0322 \\
\hline
\end{tabular}

take a role of nutrient acquisition from soil resources, nutrient requirements of forest trees may be implied by allocation of more carbon to belowground structures than aboveground parts, based on the balanced-growth hypothesis (Shipley and Meziane 2002). Although we cannot suggest that low belowground production/NPP implies high nutrient availability or high site productivity without soil or stand productivity data in this study, belowground production or its proportion to NPP may become one of indicators for site productivity if further data about site factors is supported.

In this study, fine root production was estimated in the upper soil layer up to $21 \mathrm{~cm}$ depth, because soil core samples could not be collected below $20 \mathrm{~cm}$ in gravel soil of the study site. Previous study reported that over $70 \%$ of fine roots were concentrated in the upper soil layer in this study site. Although soil core technique is an effective method for fine root study and many previous studies investigated fine roots in the top of the soil profile using this technique, it can underestimate fine root production and mortality (Clark et al. 2001a, b). However, most of the roots are more likely to be present in the top soil layer, decreasing exponentially with increasing soil depth in most ecosystems (Zhou et al. 2016a, b). Also, deep roots probably play a relatively small role in belowground carbon budget (Hendrick and Pregitzer 1996) as shown by other studies of temperate tree species which reported an increase in fine root turnover time with depth, with the most rapid fine root turnover occurring in the upper $20 \mathrm{~cm}$ (Gaudinski et al. 2001; Baddeley and Watson 2005a, b).

The annual FRPic was significantly lower than that estimated using the sequential soil core method in this study. Several researchers have reported obtaining lower estimated values of fine root production when using the ingrowth core method than when using the sequential soil core method (Makkonen and Helmisaari 1999; Ostonen et al. 2005). Makkonen and Helmisaari (1999) reported that the fine root production in the ingrowth cores after 3 years of installation was similar to the value estimated using soil cores in Scots pine stands. The production of fine roots, as estimated using the ingrowth core method, tended to have lower estimates in the first year of the ingrowth core than in the following year (Persson 1980; Yin et al. 1989; Messier and Puttonen 1993; Ostonen et al. 2005).The reason for the low fine root production estimated using the ingrowth core method may involve unfavorable soil conditions for starting root growth, the absence of older roots, and delayed root re-colonization (Joslin and Henderson 1987; Vogt and Persson 1991; Idol et al. 2000).

Noguchi et al. (2007) reviewed studies of fine root biomass and production in Japanese forests. The estimated values of fine root production for hinoki cypress plantations ranged from 122 to $306 \mathrm{~g} \mathrm{~m}^{-2} \mathrm{yr}^{-1}$ (Kasuya et al. 1993; Tokuchi et al. 2002; Hishi and Takeda 2005a, b), and the values of FRP in deciduous broadleaved forests ranged from 90 to $680 \mathrm{~g} \mathrm{~m}^{-2} \mathrm{yr}^{-1}$ (Satomura 2003; Tateno et al. 2004; Tripathi et al. 2005). The estimates of FRP obtained in this study were in the range of reported values and the values obtained in this study do not appear to deviate significantly from the reported range. The study of fine root dynamics was also conducted in konara oak stand of Ryukoku Forest from March to September 2012 (Van Do et al. 2015a; Do et al. 2015b). They reported that the FRPsc values ranged from 232 to $311 \mathrm{~g} \mathrm{~m}^{-2}$ for 174 days according to root size classes and calculation intervals. Compared with our results, the all values were higher than the FRPsc value $\left(181 \mathrm{~g} \mathrm{~m}^{-2}\right.$ for 188 days from June to December 2013) in this study.

The temporal patterns of fine root dynamics may be affected by changes in stand conditions, such as soil temperature, moisture, and nutrients, as well as carbon allocation patterns (Makkonen and Helmisaari 1998; Pregitzer et al. 2000; Lopez et al. 2001). In this study, significant differences in fine root bio- and necromass were observed between the two forests and sampling times. Also, the seasonal patterns of fine root bio- and necromass varied between root diameter classes. The low fine root biomass observed during early summer and high necromass of very fine root in August 2013 in CO2 might be attributable to very low precipitation during early summer. On the other hand, the fine root necromass in hinoki cypress stands showed significantly different 
Fig. 4 Seasonal dynamics of fine root production $(\mathbf{a}, \mathbf{b})$, mortality (c, d), and decomposition (e, f) estimated by sequential soil cores and calculated by the simplified decision matrix (Yuan and Chen 2013).Vertical bars indicate standard errors $(n=10)$. Mean values with the same letters do not differ significantly across months within each stand $(p<0.05$; Tukey's HSD test)

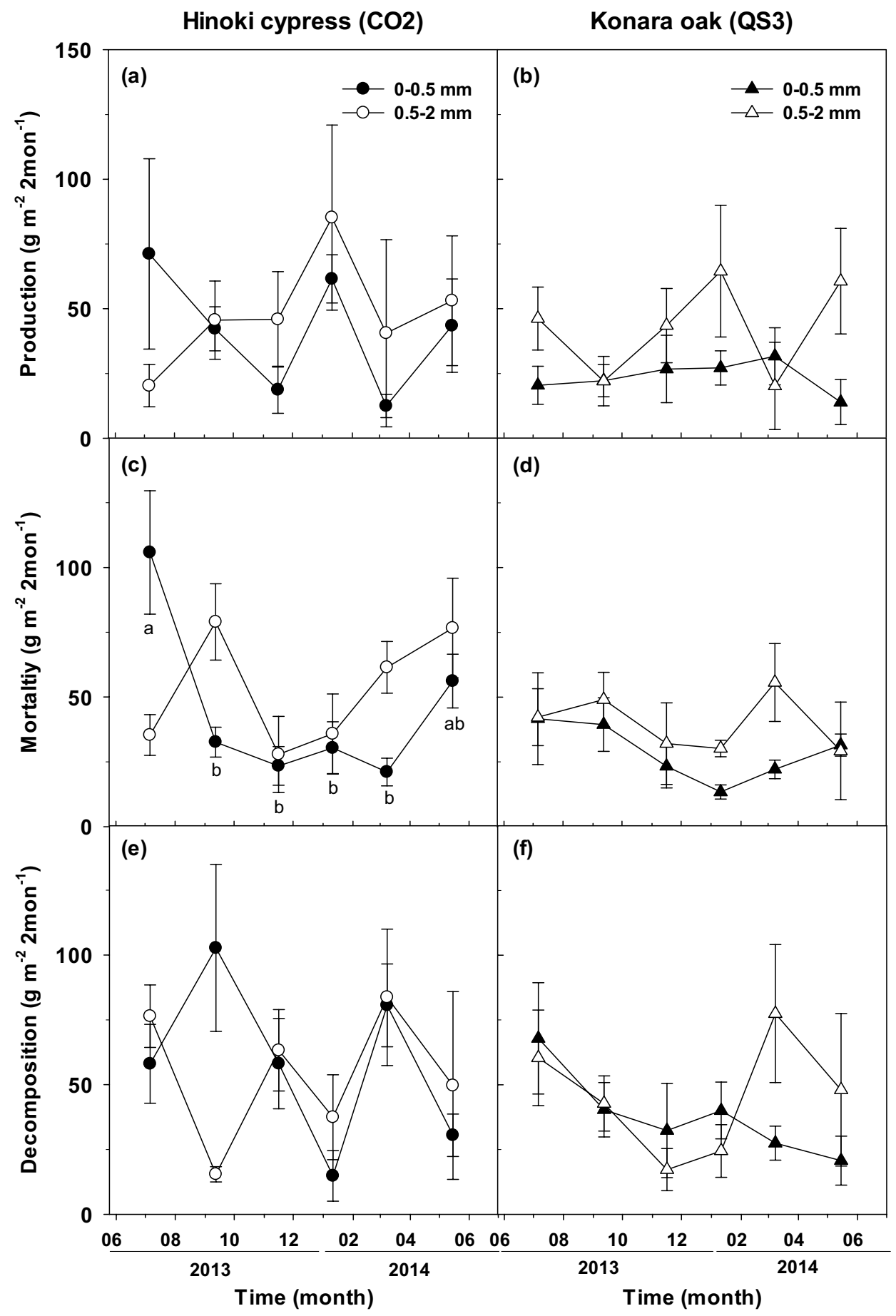

peak from June to August 2013 and from October 2013 to June 2014. According to a study performed by Hattori (2011), which was conducted in a nearby konara oak forest at the same study site, the maximum fine root biomass and necromass values were observed in October and in November, respectively. The peaks and troughs of fine root mass reported by Hattori (2011) do not exactly correspond to the patterns of fine root mass observed in this study, whereas the relatively high fine root biomass observed in February 2014 is consistent with that previous study. Meanwhile, although several researchers hypothesized that deciduous trees have a higher fine root biomass than coniferous trees 
Table $5 F$ and $p$ values of the effects of stand (S), month (M), and fine root diameter (D) on fine root production, mortality, and decomposition estimated by the sequential soil core method and the simplified decision matrix in CO2 and QS3 using a three-way ANOVA

\begin{tabular}{|c|c|c|c|}
\hline & $d f$ & $F$ value & $p$ value \\
\hline \multicolumn{4}{|l|}{ Production } \\
\hline Stand (S) & 1 & 2.37 & 0.1248 \\
\hline Month (M) & 5 & 1.53 & 0.1817 \\
\hline Diameter (D) & 1 & 2.91 & 0.0894 \\
\hline $\mathrm{S} * \mathrm{M}$ & 5 & 0.39 & 0.852 \\
\hline $\mathrm{S}^{*} \mathrm{D}$ & 1 & 0.65 & 0.4198 \\
\hline$M * D$ & 5 & 0.82 & 0.5392 \\
\hline $\mathrm{S}^{*} \mathrm{M}^{*} \mathrm{D}$ & 5 & 1.18 & 0.3202 \\
\hline \multicolumn{4}{|l|}{ Mortality } \\
\hline Stand (S) & 1 & 7.1 & 0.0083 \\
\hline Month (M) & 5 & 3.34 & 0.0062 \\
\hline Diameter (D) & 1 & 2.97 & 0.0862 \\
\hline $\mathrm{S} * \mathrm{M}$ & 5 & 1.22 & 0.3028 \\
\hline $\mathrm{S}^{*} \mathrm{D}$ & 1 & 0.1 & 0.7571 \\
\hline$M * D$ & 5 & 3.4 & 0.0056 \\
\hline $\mathrm{S} * \mathrm{M} * \mathrm{D}$ & 5 & 1.94 & 0.0884 \\
\hline \multicolumn{4}{|c|}{ Decomposition } \\
\hline Stand (S) & 1 & 3.2 & 0.0752 \\
\hline Month (M) & 5 & 2.47 & 0.0332 \\
\hline Diameter (D) & 1 & 0.06 & 0.814 \\
\hline $\mathrm{S} * \mathrm{M}$ & 5 & 0.69 & 0.6284 \\
\hline$S^{*} \mathrm{D}$ & 1 & 0.4 & 0.5295 \\
\hline$M * D$ & 5 & 1.62 & 0.1569 \\
\hline$S * M * D$ & 5 & 1.6 & 0.162 \\
\hline
\end{tabular}

in the temperate zone (Vogt et al. 1986, 1996; Leuschner and Hertel 2003; Finér et al. 2007; Noguchi et al. 2007), the higher fine root biomass in the hinoki cypress stand than in the konara oak stand is not consistent with previously reported results.

Several researchers reported that the seasonal dynamics of fine root production are affected by nutrient availability, environmental conditions (Vogt et al. 1996; Alvarex-Uria and Körner 2007; Finér et al. 2011), species composition (Lei et al. 2012), and stand age (Helmisaari et al. 2002; Yang et al. 2010; Yuan and Chen 2012a, b). Fine root production
$(<2 \mathrm{~mm})$ did not show clear pattern in both stands of this study. Nakahata (2016) investigated long-term observation of fine root production using a root scanner method in hinoki cypress and konara oak stands in the Ryukoku Forest. He found a summer unimodal pattern with a high production rate from July to August in hinoki cypress stand in 2013 and a bimodal pattern with two peaks between mid-spring and early summer, and between mid-summer and early autumn, respectively, in hinoki cypress stand in 2014 and konara oak stand in 2013 and 2014. The fine root mortality was relatively high from April to June, and it might be induced by low soil temperature rather than air temperature in March 2014 as a result of suppressing fine root growth.

We found no significant relationships between fine root production and basal area increment or leaf litterfall production. Previously, Santantonio (1989) found a linear relationship between fine root and foliage biomass for several conifer species, and a positive linear relationship between annual leaf litterfall and fine root mass in semi-arid tree species was observed by Jha and Mohapatra (2010). Also, a positive linear relationship between fine root production and litterfall was reported in a warm-temperate evergreen broadleaved forest (Van Do et al. 2015a; Do et al. 2015b). Contrary to previous studies, Nadelhoffer and Raich (1992) observed no overall relationship between aboveground production and fine root production with a large data set. However, a marginally positive correlation between above- and belowground net primary production was detected in this study, even though the data are only from four stands. Belowground production increased with aboveground production, given that independent analyses of forest $\mathrm{C}$ and $\mathrm{N}$ budgets suggest a linkage between these two components of net primary production (Nadelhoffer and Raich 1992). This finding is consistent with the significant relationship observed between above- and belowground NPP in this study. Furthermore, we found that fine root production might increase with increasing NPP suggesting high allocation to belowground in high productive stands. Similar to our results, Litton et al. (2007) reviewed literature and reported that a positive correlation between ANPP and total belowground carbon flux was observed across a broad productivity gradient, and carbon fluxed to belowground production increased with increasing GPP. 

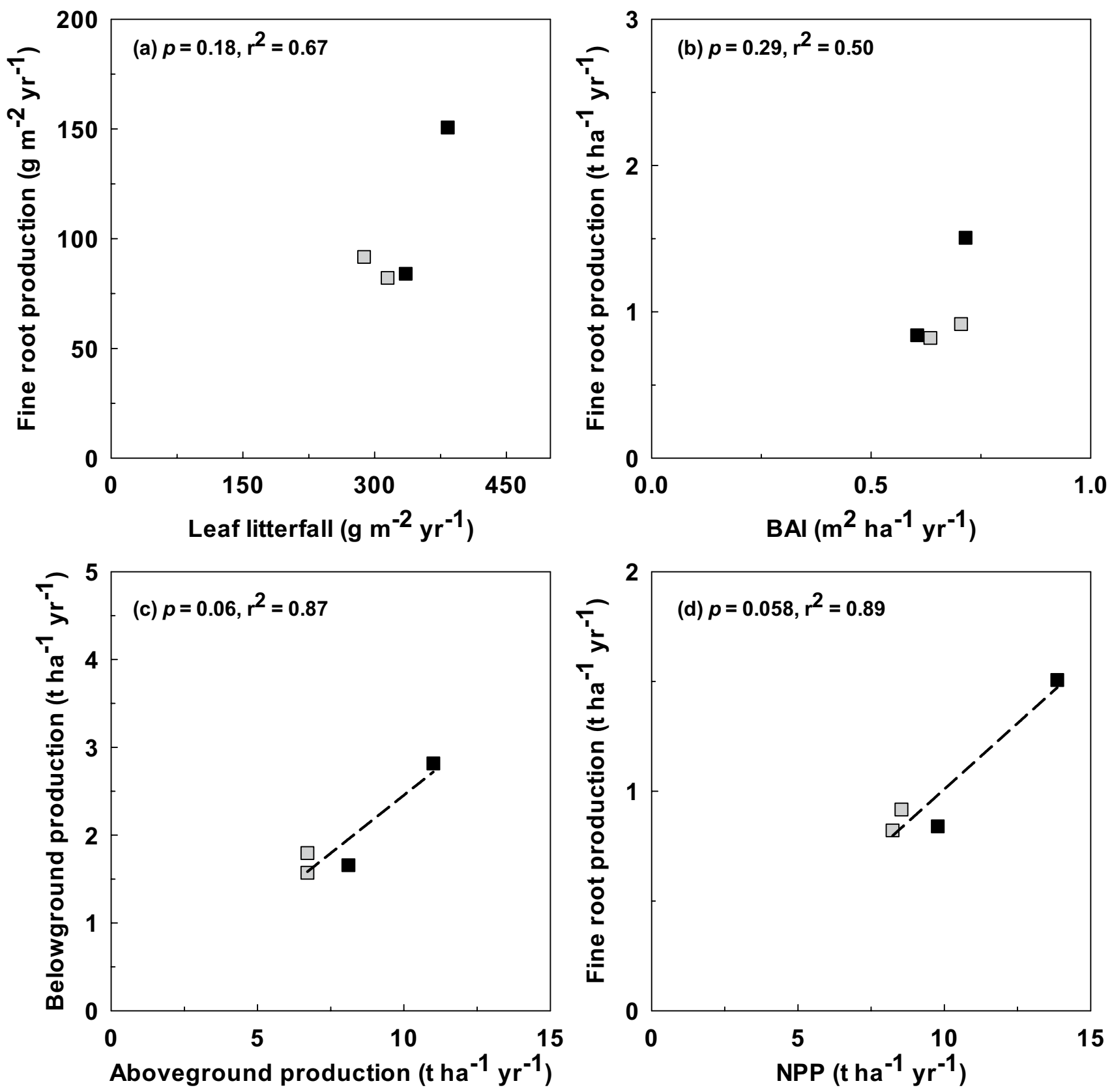

- Hinoki cypress stands (CO1, CO2)

$\square \quad$ Konara oak stands (QS2, QS3)

Fig. 5 Relationships between a leaf litterfall and fine root production, b basal area increment (BAI) and fine root production, $\mathbf{c}$ above- and belowground production, $\mathbf{d}$ net primary production (NPP) and fine

\section{Conclusions}

We clarified the role and significance of fine roots in forest ecosystems through a stand-level study. The probable ranges of fine root production, mortality, and root production in hinoki cypress $(\mathrm{CO} 1$ and $\mathrm{CO} 2)$ and konara oak (QS2 and QS3) stands in the Ryukoku Forest. Dashed lines show a marginally significant relationship $(\mathbf{c}, \mathbf{d})$

decomposition were estimated using two soil core techniques for hinoki cypress and konara oak forests in Japan. The estimated values of fine root characteristics varied depending on the measurement method, representing lower production values by ingrowth coring than sequential soil 
coring. Seasonal patterns of fine root bio- and necromass differed between two forest types and thinner root showed more distinct seasonal changes than thicker root. No overall seasonal patterns of fine root production were found regardless of forest types. However, we found that carbon allocation to belowground fine roots seemed to be positively related with forest productivity. This study can contribute to improve our understanding of carbon allocation patterns in temperate forest ecosystems.

Acknowledgements We would like to thank Prof. T. Miyaura of Ryukoku University for allowing the work in the Ryukoku Forest. In addition, we appreciate Dr. N. Kurachi of Ryukoku University for helping with field work, giving us valuable comments about the research, and allowing us to use her bootstrap method program to calculate production, mortality, and decomposition of fine roots. We also thank R. Nakahata, Y. Nishino, and M. Ishii for helping with field work at the Ryukoku Forest. This research was supported by Basic Science Research Program through the National Research Foundation of Korea (NRF) funded by the Ministry of Education (2019R1A6A3A0109122712) and the Sasakawa Scientific Research Grant from The Japan Science Society (Grant number: 28-527).

Author contributions statement JYA and AO contributed to the study conception and design. Material preparation, data collection and analysis were performed by JYA. The first draft of the manuscript was written by JYA and AO commented on previous versions of the manuscript. All authors read and approved the final manuscript.

\section{Compliance with ethical standards}

Conflict of interest The authors declare no conflict of interest.

Open Access This article is licensed under a Creative Commons Attribution 4.0 International License, which permits use, sharing, adaptation, distribution and reproduction in any medium or format, as long as you give appropriate credit to the original author(s) and the source, provide a link to the Creative Commons licence, and indicate if changes were made. The images or other third party material in this article are included in the article's Creative Commons licence, unless indicated otherwise in a credit line to the material. If material is not included in the article's Creative Commons licence and your intended use is not permitted by statutory regulation or exceeds the permitted use, you will need to obtain permission directly from the copyright holder. To view a copy of this licence, visit http://creativecommons.org/licenses/by/4.0/.

\section{References}

Ågren GI, Axelsson B, Flower-Ellis JGK et al (1980) Annual carbon budget of a young Scots pine. Ecol Bull 32:307-313

Alvarex-Uria P, Körner C (2007) Low temperature limits of root growth in deciduous and evergreen temperate tree species. Funct Ecol 21:211-218. https://doi.org/10.1111/j.1365-2435.2007.01231.x

Baddeley JA, Watson CA (2005) Influences of root diameter, tree age, soil depth and season on fine root survivorship in Prunus avium. Plant Soil 276:15-22. https://doi.org/10.1007/s1110 4-005-0263-6
Baddeley JA, Watson CA (2005) Influences of root diameter, tree age, soil depth and season on fine root survivorship in Prunus avium. Plant Soil 276:15-22. https://doi.org/10.1007/s1110 4-005-0263-6

Bardgett RD, Mommer L, De Vries FT (2014) Going underground: root traits as drivers of ecosystem processes. Trends Ecol Evol 29:692-699. https://doi.org/10.1016/J.TREE.2014.10.006

Brassard BW, Chen HYH, Bergeron Y (2009) Influence of environmental variability on root dynamics in northern forests. CRC Crit Rev Plant Sci 28:179-197. https://doi.org/10.1080/07352 680902776572

Cheng X (2017) Net primary production and fine root dynamics in stands of Ilex pedunculosa Miq. Kyoto University

Clark D, Brown S, Kicklighter DW et al (2001) Measuring net primary production in forests: concepts and field methods. Ecol Appl $11: 356-370$

Clark DA, Brown S, Kicklighter DW et al (2001) Measuring net primary production in forests: concepts and field methods. Ecol Appl 11:356-370

Dannoura M, Suzuki M, Kominami Y et al (2006) Estimation of root biomass and root surface area in a broad-leaved secondary forest in the Southern part of Kyoto Prefecture. J Japanese For Soc $88: 120-125$

Dixon RK, Brown S, Houghton RA et al (1994) Carbon pools and flux of global forest ecosystems. Science 263:185-190. https://doi. org/10.1126/science.263.5144.185

Efron B (1979) Bootstrap methods: another look at jackknife. Ann Stat 7:1-26. https://doi.org/10.1214/aoms/1177692541

Efron B, Gong G (1983) A leisurely look at the bootstrap, the jackknife, and cross-validation. Am Stat 37:36-48. https://doi. org/10.2307/2685844

Eissenstat DM, Yanai RD (1997) The ecology of root lifespan. In: Advances in ecological research. pp\&nbsp;1-60

Fairley RI, Alexander IJ (1985) Methods of calculating fine root production in forests. In: Fitter AH, Atkinson D, Read DJ (eds) Ecological interactions in soils: plants, microbes and animals. Blackwell, Oxford, pp 37-42

Fang J, Guo Z, Hu H et al (2014) Forest biomass carbon sinks in East Asia, with special reference to the relative contributions of forest expansion and forest growth. Glob Chang Biol 20:2019-2030. https://doi.org/10.1111/gcb.12512

Finér L, Messier C, De Grandpré L (1997) Fine-root dynamics in mixed boreal conifer - broad-leafed forest stands at different successional stages after fire. Can J For Res 27:304-314

Finér L, Helmisaari HS, Lõhmus K et al (2007) Variation in fine root biomass of three European tree species: Beech (Fagus sylvatica L.),Norwayspruce (Picea abies L. Karst.) and Scots pine (Pinus sylvestris L.). Plant Biosyst 141:394-405

Finér L, Ohashi M, Noguchi K, Hirano Y (2011) Fine root production and turnover in forest ecosystems in relation to stand and environmental characteristics. For Ecol Manage 262:20082023. https://doi.org/10.1016/j.foreco.2011.08.042

Gaudinski J, Trumbore S, Davidson E et al (2001) The age of fineroot carbon in three forests of the eastern United States measured by radiocarbon. Oecologia 129:420-429. https://doi. org/10.1007/s004420100746

Gill RA, Jackson RB (2000) Global patterns of root turnover for terrestrial ecosystems. New Phytol 147:13-31

Girardin C, Malhi Y (2010) Net primary productivity allocation and cycling of carbon along a tropical forest elevational transect in the Peruvian Andes. Glob Chang Biol 16:3176-3192. https ://doi.org/10.1111/j.1365-2486.2010.02235.x

Gower S, Krankina O, Olson R (2001) Net primary production and carbon allocation patterns of boreal forest ecosystems. Ecol Appl 11:1395-1411 
Hagihara A, Taketo Y, Kazuharu O (1993) Allometric relations in hinoki (Chamaecyparis obtusa (Sieb. et Zucc.) Endl.) trees. Bull Nagoya Univ For 12:11-29

Hattori K (2011) The pipe-model and quantitative relationships of leaf biomass and fine root biomass in forest communities. Kyoto University

Helmisaari H-S, Makkonen K, Kellomaki S et al (2002) Below- and above-ground biomass, production and nitrogen use in Scots pine stands in eastern Finland. For Ecol Manage 165:317-326

Helmisaari H-S, Derome J, Nöjd P, Kukkola M (2007) Fine root biomass in relation to site and stand characteristics in Norway spruce and Scots pine stands. Tree Physiol 27:1493-1504. https://doi.org/10.1093/treephys/27.10.1493

Hendrick RL, Pregitzer KS (1996) Temporal and depth-related patterns of fine root dynamics in northern hardwood forests. J Ecol 84:167-176

Hertel D, Leuschner C (2002) A comparison of four different fine root production estimates with ecosystem carbon balance data in a Fagus-Quercus mixed forest. Plant Soil 239:237-251

Hertel D, Moser G, Culmsee H et al (2009) Below- and aboveground biomass and net primary production in a paleotropical natural forest (Sulawesi, Indonesia) as compared to neotropical forests. For Ecol Manage 258:1904-1912

Hishi T, Takeda H (2005a) Life cycles of individual roots in fine root system of Chamaecyparis obtusa Sieb. et Zucc. J For Res 10:181-187. https://doi.org/10.1007/s10310-004-0120-0

Hishi T, Takeda H (2005b) Dynamics of heterorhizic root systems: Protoxylem groups within the fine-root system of Chamaecyparis obtusa. New Phytol 167:509-521

Idol TW, Pope PE, Ponder F (2000) Fine root dynamics across a chronosequence of upland temperate deciduous forests. For Ecol Manage 127:153-167

Ishii M (2014) Changes in production structure of Japanese cypress plantation through thinning in Ryukoku Forest. Ryukoku University

Iversen CM (2010) Digging deeper: fine-root responses to rising atmospheric $\mathrm{CO}_{2}$ concentration in forested ecosystems. New Phytol 186:346-357. https://doi.org/10.1111/J.1469-

Iversen CM, Norby RJ (2008) Nitrogen limitation in a sweetgum plantation: implications for carbon allocation and storage. Can J For Res 38:1021-1032. https://doi.org/10.1139/X07-213

Jackson R, Mooney HA, Schulze ED (1997) A global budget for fine root biomass, surface area, and nutrient contents. Proc Natl Acad Sci USA 94:7362-7366

Janssens IA, Sampson DA, Curiel-Yuste J et al (2002) The carbon cost of fine root turnover in a Scots pine forest. For Ecol Manage 168:231-240

Jha P, Mohapatra KP (2010) Leaf litterfall, fine root production and turnover in four major tree species of the semi-arid region of India. Plant Soil 326:481-491. https://doi.org/10.1007/s1110 4-009-0027-9

Joslin JD, Henderson GS (1987) Organic matter and nutrients associated with fine root turnover in a white oak stand. For Sci 33:330-346

Kasuya N, Takeda H, Iwatsubo G (1993) Turnover rates of fi ne roots in a Chamecyparis obtusa forest (in Japanese). Trans Kansai Jpn Soc 2:65-68

Keyes MR, Grier CC (1981) Above- and below- ground net production in 40-year-old Douglas-fir stands on low and high productivity sites. Can J For Res 11:599-605

Lei P, Scherer-Lorenzen M, Bauhus J (2012) The effect of tree species diversity on fine-root production in a young temperate forest. Oecologia 169:1105-1115

Leppälammi-Kujansuu J, Aro L, Salemaa M et al (2014) Fine root longevity and carbon input into soil from below- and aboveground litter in climatically contrasting forests. For
Ecol Manage 326:79-90. https://doi.org/10.1016/j.forec o.2014.03.039

Leuschner C, Hertel D (2003) Fine root biomass of temperate forests in relation to soil acidity and fertility, climate, age and species. Prog Bot 64:405-438

Litton C, Raich J, Ryan M (2007) Carbon allocation in forest ecosystems. Glob Chang Biol 13:2089-2109

Lopez B, Sabate S, Gracia CA (2001) Annual and seasonal changes in fine root biomass of a Quercus ilex L. forest. Plant Soil 230:125-134

Luo T, Li W, Zhu H (2002) Estimated biomass and productivity of natural vegetation on the Tibetan Plateau. Ecol Appl 12:980-997

Majdi H (1996) Root sampling methods - applications and limitations of the minirhizotron technique. Plant Soil 185:255-258

Majdi H, Pregitzer K, Morén A-S et al (2005) Measuring fine root turnover in forest ecosystems. Plant Soil 276:1-8. https://doi. org/10.1007/s11104-005-3104-8

Makkonen K, Helmisaari HS (1998) Seasonal and yearly variations of fine-root biomass and necromass in a Scots pine (Pinus sylvestris L.) stand. For Ecol Manage 102:283-290. https://doi. org/10.1016/S0378-1127(97)00169-2

Makkonen K, Helmisaari HS (1999) Assessing fine-root biomass and production in a Scots pine stand - comparison of soil core and root ingrowth core methods. Plant Soil 210:43-50. https://doi. org/10.1023/A:1004629212604

McCormack ML, Eissenstat DM, Prasad AM, Smithwick EAH (2013) Regional scale patterns of fine root lifespan and turnover under current and future climate. Glob Chang Biol 19:1697-1708. https://doi.org/10.1111/gcb.12163

McCormack ML, Adams TS, Smithwick EAH, Eissenstat DM (2014) Variability in root production, phenology, and turnover rate among 12 temperate tree species. Ecology 95:2224-2235. https ://doi.org/10.1890/13-1942.1

McCormack ML, Dickie I, Eissenstat DM et al (2015) Redefining fine roots improves understanding of below-ground contributions to terrestrial biosphere processes. New Phytol 207:505518. https://doi.org/10.1111/nph.13363

Messier C, Puttonen P (1993) Coniferous and non-coniferous fineroot and rhizome production in Scots pine stands using the ingrowth bag method. Silva Fenn 27:209-217

Nadelhoffer KJ, Raich JW (1992) Fine root production estimates and belowground carbon allocation in forest ecosystems. Ecology 73:1139-1147

Nadelhoffer KJ, Aber JD, Melillo JM (1985) Fine roots, net primary production, and soil nitrogen availability: a new hypothesis. Ecology 66:1377-1390

Nakahata R (2016) Long-term observation of fine root production using a root scanner method in hinoki cypress and konara oak forests. Kyoto University

Nakahata R, Osawa A (2017) Fine root dynamics after soil disturbance evaluated with a root scanner method. Plant Soil 419:467-487. https://doi.org/10.1007/s11104-017-3361-3

Naruse K (2008) Biomass of a secondary Quercus serrata stand at Ryukoku Forest. Ryukoku University

Noguchi K, Konôpka B, Satomura T et al (2007) Biomass and production of fine roots in Japanese forests. J For Res 12:83-95. https ://doi.org/10.1007/s10310-006-0262-3

Ogawa H, Kira T (1977) Methods of estimating forest biomass. In: Shidei T, Kira T (eds) Primary productivity of Japanese forestproductivity of terrestrial communities. University of Tokyo Press, Tokyo, pp 15-25

O'Grady AP, Worledge D, Battaglia M (2006) Above- and belowground relationships, with particular reference to fine roots, in a young Eucalyptus globulus (Labill.) stand in southern Tasmania. 
Trees Struct Funct 20:531-538. https://doi.org/10.1007/s0046 8-006-0055-5

Osawa A, Aizawa R (2012) A new approach to estimate fine root production, mortality, and decomposition using litter bag experiments and soil core techniques. Plant Soil 355:167-181. https:// doi.org/10.1007/s11104-011-1090-6

Ostle NJ, Smith P, Fisher R et al (2009) Integrating plant-soil interactions into global carbon cycle models. J Ecol 97:851-863. https ://doi.org/10.1111/j.1365-2745.2009.01547.x

Ostonen I, Lõhmus K, Pajuste K (2005) Fine root biomass, production and its proportion of NPP in a fertile middle-aged Norway spruce forest: Comparison of soil core and ingrowth core methods. For Ecol Manage 212:264-277. https://doi.org/10.1016/j. foreco.2005.03.064

Persson H (1980) Fine-root dynamics in a Scots pine stand with and without near optimum nutrient and water regimes. Acta Phytogeogr Suec 68:101-110

Pregitzer KS, King JS, Burton AJ, Brown SE (2000) Responses of tree fine roots to temperature. New Phytol 147:105-115

Ruess RW, Hendrick RL, Burton AJ et al (2003) Coupling Fine Root Dynamics with Ecosystem Carbon Cycling in Black Spruce Forests of Interior Alaska. Ecol Monogr 73:643-662. https://doi. org/10.1890/02-4032

Santantonio D (1989) Dry-matter partitioning and fine-root production in forests - new approaches to a difficult problem. In: Pereira JS, Landsberg JJ (eds) Biomass Production by Fast-Growing Trees. Springer Netherlands, Dordrecht, pp\&nbsp;57-72

Santantonio D, Grace JC (1987) Estimating fine root production and turnover from biomass and decomposition data: a compartment flow model. Can J For Res 17:900-908

Satomura T (2003) Biomass of fine roots and mycorrhizal fungi in forest ecosystems (in Japanese with English summary). Hiroshima University, Japan

Satomura T, Hashimoto Y, Koizumi H et al (2006) Seasonal patterns of fine root demography in a cool-temperate deciduous forest in central Japan. Ecol Res 21:741-753. https://doi.org/10.1007/ s11284-006-0182-x

Shipley B, Meziane D (2002) The balanced-growth hypothesis and the allometry of leaf and root biomass allocation. Funct Ecol 16:326-331. https://doi.org/10.1046/j.1365-2435.2002.00626.x

Steele SJ, Gower ST, Vogel JG, Norman JM (1997) Root mass, net primary production and turnover in aspen, jack pine and black spruce forests in Saskatchewan and Manitoba, Canada. Tree Physiol 17:577-587

Sun T, Mao Z, Dong L et al (2013) Further evidence for slow decomposition of very fine roots using two methods: Litterbags and intact cores. Plant Soil 366:633-646. https://doi.org/10.1007/ s11104-012-1457-3

Tateno R, Hishi T, Takeda H (2004) Above- and belowground biomass and net primary production in a cool-temperate deciduous forest in relation to topographical changes in soil nitrogen. For Ecol Manage 193:297-306. https://doi.org/10.1016/j.forec o.2003.11.011

Tierney GL, Fahey TJ, Groffman PM et al (2003) Environmental control of fine root dynamics in a northern hardwood forest. Glob Chang Biol 9:670-679. https://doi.org/10.104 6/j.1365-2486.2003.00622.x

Tokuchi N, Fujimaki R, Terai M et al (2002) Soil nitrogen dynamics of temperate conifer forest in central Japan: the case study of Japanese cypress forest at Kamigamo Experimental Forest (in Japanese with English summary). Res Kyoto 74:47-52

Tripathi SK, Sumida A, Shibata H et al (2005) Growth and substrate quality of fine root and soil nitrogen availability in a young Betula ermanii forest of northern Japan: Effects of the removal of understory dwarf bamboo (Sasa kurilensis). For Ecol Manage 212:278-290. https://doi.org/10.1016/j.foreco.2005.03.030
Trumbore SE, Gaudinski JB (2003) The secret lives of roots. Science 302:1344-1345

Van Do T, Osawa A, Sato T (2015a) Estimation of fine-root production using rates of diameter-dependent root mortality, decomposition and thickening in forests. Tree Physiol 00:1-11. https ://doi.org/10.1093/treephys/tpv121

Van Do T, Sato T, Saito S, Kozan O (2015b) Fine-root production and litterfall: main contributions to net primary production in an old-growth evergreen broad-leaved forest in southwestern Japan. Ecol Res 30:921-930. https://doi.org/10.1007/s1128 4-015-1295-X

Vesterdal L, Clarke N, Sigurdsson BD, Gundersen P (2013) Do tree species influence soil carbon stocks in temperate and boreal forests? For Ecol Manage 309:4-18. https://doi.org/10.1016/j. foreco.2013.01.017

Vogt KA, Persson H (1991) Measuring growth and development of roots. In: Lassoie JP, Hinckley TM (eds) Techniques and Approaches in Forest Tree Ecophysiology. CRC Press, Boca Raton, pp\&nbsp;477-501

Vogt KA, Grier CC, Vogt DJ (1986) Production, turnover, and nutrient dynamics of above- and belowground detritus of world forests. Adv Ecol Res 15:303-377

Vogt KA, Vogt DJ, Moore EE et al (1987) Conifer and angiosperm fine root biomass in relation to stand age site productivity in Douglas-fir forests. J Ecol 75:857-870

Vogt KA, Vogt DJ, Palmiotto PA et al (1996) Review of root dynamics in forest ecosystems grouped by climate, climatic forest type and species. Plant Soil 187:159-219

Xiao C-W, Yuste JC, Janssens I et al (2003) Above- and belowground biomass and net primary production in a 73-year-old Scots pine forest. Tree Physiol 23:505-516

Xu B, Yang Y, Li P et al (2014) Global patterns of ecosystem carbon flux in forests: A biometric data-based synthesis. Global Biogeochem Cycles 28:962-973. https://doi.org/10.1002/2013G B004593

Yang L, Wu S, Zhang L (2010) Fine root biomass dynamics and carbon storage along a successional gradient in Changbai Mountains, China. Forestry 83:379-387. https://doi.org/10.1093/ forestry/cpq020

Yin X, Perry JA, Dixon RK (1989) Fine-root dynamics and biomass distribution in a Quercus ecosystem following harvesting. For Ecol Manage 27:159-177. https://doi.org/10.1016/03781127(89)90105-9

Yuan ZY, Chen H (2010a) Fine root biomass, production, turnover rates, and nutrient contents in boreal forest ecosystems in relation to species, climate, fertility, and stand age: literature review and meta-analyses. CRC Crit Rev Plant Sci 29:204-221. https://doi. org/10.1080/07352689.2010.483579

Yuan ZY, Chen HYH (2010b) Fine root biomass, production, turnover rates, and nutrient contents in boreal forest ecosystems in relation to species, climate, fertility, and stand age: Literature review and meta-analyses. CRC Crit Rev Plant Sci 29:204-221. https://doi. org/10.1080/07352689.2010.483579

Yuan ZY, Chen HYH (2012a) A global analysis of fine root production as affected by soil nitrogen and phosphorus. Proc R Soc B Biol Sci 279:3796-3802. https://doi.org/10.1098/rspb.2012.0955

Yuan ZY, Chen HYH (2012b) Fine root dynamics with stand development in the boreal forest. Funct Ecol 26:991-998

Yuan ZY, Chen HYH (2013) Simplifying the decision matrix for estimating fine root production by the sequential soil coring approach. Acta Oecol 48:54-61. https://doi.org/10.1016/j.actao 2013.01.009

Zak DR, Pregitzer KS (1998) Integration of ecophysiological and biogeochemical approaches to ecosystem dynamics. In: Pace ML, Groffman PM (eds) Successes Limit Front Ecosyst Sci. Springer New York, New York, pp 372-403 
Zhou H, Zhao W, Yang Q (2016) Root biomass distribution of planted Haloxylon ammodendron in a duplex soil in an oasis: desert boundary area. Ecol Res 31:673-681. https://doi.org/10.1007/ s11284-016-1376-5

Zhou H, Zhao W, Yang Q (2016b) Root biomass distribution of planted Haloxylon ammodendron in a duplex soil in an oasis: desert boundary area. Ecol Res 31:673-681. https://doi.org/10.1007/ s11284-016-1376-5

Publisher's Note Springer Nature remains neutral with regard to jurisdictional claims in published maps and institutional affiliations. 